\title{
EVALUATION OF FINANCIAL STABILITY AND HEALTH OF MUNICIPALITIES
}

\author{
[Evaluace finanční stability a zdraví obcí] \\ Irena Szarowská ${ }^{1}$, Ingrid Majerová ${ }^{2}$, Jarmila Šebestová $^{3}$, Marian Lebiedzik $^{4}$, Radim \\ Dolák $^{5}$ \\ ${ }^{1}$ Slezská univerzita, Obchodně podnikatelská fakulta, Univerzitní nám. 1934/3,733 40 Karviná \\ Email:szarowska@opf.slu.cz \\ ${ }^{2}$ Slezská univerzita, Obchodně podnikatelská fakulta, Univerzitní nám. 1934/3,733 40 Karviná \\ Email:majerova@opf.slu.cz \\ ${ }^{3}$ Slezská univerzita, Obchodně podnikatelská fakulta, Univerzitní nám. 1934/3,733 40 Karviná \\ Email:sebestova@opf.slu.cz \\ ${ }^{4}$ Slezská univerzita, Obchodně podnikatelská fakulta, Univerzitní nám. 1934/3,733 40 Karviná \\ Email:lebiedzik@opf.slu.cz \\ ${ }^{5}$ Slezská univerzita, Obchodně podnikatelská fakulta, Univerzitní nám. 1934/3,733 40 Karviná \\ Email:dolak@opf.slu.cz
}

\begin{abstract}
Financial stability of municipalities is an important aspect for long-term sustainable development and disproportionate debt can generate risks for their standard functioning. Although there are many methodologies for assessing the financial stability and health of municipalities, they are usually based on central government needs and are not used for financial management and planning. The aim of the article is to develop a set of indicators for assessing financial stability and health for needs of municipalities by using publicly available information. The selected indicators highlight two basic assumptions important for short and long-term budget balance and sustainability of funding. Concretely, the balance of the current budget should always be positive and the maximum debt service should not exceed the surplus of the current budget. The set of indicators includes three groups of indicators: budgetary management, indebtedness and liquidity. There is a clearly defined and interpretable assessment for each indicator in terms of financial stability and potential risk.
\end{abstract}

Keywords: budget, financial stability, financial health, indebtedness, liquidity, municipality.

JEL classification: $\mathrm{H7}$, R5

Doručeno redakci: 24.4.2018; Recenzováno: 6.5.2018; 11.5.2018; Schváleno k publikování: 19.9.2018

\section{Úvod}

Stejně jako rozpočtová stabilita státu, tak i finanční stabilita (dále FS) obcí je důležitým východiskem pro jejich dlouhodobě udržitelný rozvoj. Tato potřeba vychází nejen z ekonomiky samotné, ale v př́padě členských států Evropské unie, také z potřeby nadnárodní (CEMR 2017). Ne vždy se však daří udržet zadlužení na takové úrovni, aby nezavdávalo rizika pro další bezproblémové fungování. Příčinou mohou být problémy s čerpáním dotací, „problémové“ investice i nevhodné finanční řízení obce. Mimo jiné z těchto důvodů začíná být této oblasti věnována stále větší pozornost ze strany státu. Ačkoli existuje řada př́stupů a metod pro hodnocení FS a zdraví obcí, jejich nevýhodou je, že se primárně využívají pro potřeby ústředních orgánů státní správy či zákonodárných institucí, k reportování, popř. jako podpůrný nástroj pro získání dotací či úvěrů. Navíc jsou tyto př́istupy často metodologicky komplikované, vyžadují poměrně hluboké znalosti dané problematiky a mnohé z nich jsou nabízeny na komerční bázi. Především menší obce jsou z hlediska jejich využití pří finančním řízení a plánování relativně znevýhodněny, jelikož nemají lidské zdroje pro jejich zpracování 
a limitované finanční zdroje neumožnují zpracování za úplatu. K monitoringu a hodnocení FS však lze využít povinně zveřejňované údaje, např. v rámci rozpočtu, rozvahy a výsledovky.

Hlavní motivací pro napsání článku byla potřeba ujasnění a systematizace indikátorů finanční stability a zdraví obcí, která je zároveň motivací realizace zadaného projektu Moravskoslezským krajem (MSK) na podporu kvalitnějšího a jednoduššího finančního řízení obcí a zvýšení jejich finanční stability. Cílem článku je vytvořit soustavu ukazatelů pro hodnocení finanční stability a zdraví pro potřeby obcí, která využívá veřejně dostupné informace. Hodnocení bude vycházet ze dvou základních předpokladů, které jsou důležité pro zajištění krátkodobé i dlouhodobé rozpočtové rovnováhy a udržitelnosti financování obcí. Konkrétně saldo běžného rozpočtu by vždy mělo být kladné (kapitálový rozpočet může být deficitní) a maximální dluhová služba (splátky dluhu plus placené úroky) by neměla převyšovat př́ebytek běžného rozpočtu.

Článek je strukturován následovně. Nejprve bude provedena analýza současného stavu poznání, a to jak domácí, tak zahraniční literatury. Poté budou představena legislativní východiska hospodaření a rozpočtové odpovědnosti obcí a př́stupy k hodnocení FS a zdraví. Následně budou navrženy skupiny indikátorů a zdůvodněna jejich důležitost pro FS a zdraví, včetně stanovení doporučených limitů a mezí. Závěrem bude navržená soustava zhodnocena z hlediska prŕinosu pro obce na príkladu obcí MSK.

\section{Současný stav poznání}

Posláním obce je péče o všestranný rozvoj svého území a o potřeby svých občanů a ochrana veřejného zájmu (Zákon č. 128/2000 Sb., obcích). Podobně je dle Pekové (2008) nebo Kadeřábkové a Pekové (2012) posláním obce zvelebovat vlastní majetek, zabezpečovat veřejné statky pro své občany, vytvářet podmínky pro sociálně ekonomický rozvoj svého území, koordinovat činnost ekonomických subjektů na svém území, rozvíjet potřebné vztahy a spolupracovat $s$ jinými organizacemi jak veřejného, tak soukromého sektoru včetně státu, zajistit ochranu krajiny a životního prostředí na svém území a při tom chránit veřejný zájem a zájmy a preference obyvatel i podnikatelských subjekti̊ a respektovat požadavek hospodárnosti, efektivnosti a účelnosti.

Schopnost obcí hospodárně a účelně hospodařit s finančními prostředky a majetkem, administrativně a finančně zabezpečit realizaci rozvojových projektů a pomocí ekonomických nástrojů přispívat ke zlepšení hospodářské situace a občanské vybavenosti a služeb v obci vyjadřuje dle Binka a kol. (2007) ekonomický potenciál obcí. Vzhledem k výše uvedenému je potřeba, aby obce byly finančně stabilní a zdravé. Halásková (2013) tvrdí, že odrazem finančního zdraví obcí je kvalita zabezpečování veřejných statků. Finanční stabilita a zdraví nejsou v české literatuře ani legislativě přesně specifikovány. Podle Otrusinové a Kubičkové (2011) můžeme FS a zdraví obcí posuzovat ze tř́ hledisek. Prvním je hledisko rentability, které představuje hospodárné a efektivní využívání zdrojů za účelem plnění funkcí obce, kdy kritériem rentability je úspora rozpočtových výdajů. Druhým hlediskem je schopnost uhrazovat splatné závazky při sladění potřeb (výdajů) a tvorby financí (př́ijmů). Posledním hlediskem je finanční nezávislost na dodatečných zdrojích. Žárská (2009) považuje finanční kapacitu obce za významný determinant rozvoje a zdůrazňuje provázanost FS a odpovědného finančního řízení.

Adrian a kol. (2015) zdůrazňují rozpočtové aspekty FS, nutnost důsledného monitorování a účelného využívání veřejných př́imů. Takovýto monitoring provádí každoročně Ministerstvo financí (na základě usnesení vlády ČR ze dne 12. listopadu 2008 č. 1395 o monitoringu 
hospodaření obcí), které na základě soustavy informativních a monitorujících ukazatelů (SIMU) za všechny obce a jimi zrrízené př́spěvkové organizace vypočte a vyhodnotí výsledky. Jedná se celkově o 18 ukazatelů, s výjimkou počtu obyvatel jsou všechny finančního rázu.

Obvykle se zkoumání zaměřuje na analýzu finančního zdraví ve formě bonity obce či finanční analýzy. Bonita obce je sledována (podnikateli, bankami, odbornou i laickou veřejností) prostřednictvím ratingu, jehož hlavní význam spočívá v lepších možnostech úvěrování a lepší image obce, nezanedbatelný je však také veřejně-kontrolní a politický rozměr. Komplexním systémem hodnocení hospodaření obcí se v českých podmínkách zabývá zejména Halásek a kol. (2002). Bonita podle autorů představuje kumulované vyjádření kvalitativních a kvantitativních parametrů hospodaření obce. Podle Haláska a kol. (2005 a 2006) upravené pojetí bonity vychází ze souboru finančních a ekonomických ukazatelů souvisejících $\mathrm{s}$ hospodařením a majetkem obcí, které jsou obsaženy $\mathrm{v}$ rozpočtu, dalších výkazech a dokumentech obce, demografických údajů za obce a dalších údajů o kvalitě území, ve kterém se obec nachází. Celková bonita se člení na dílčí bonity, a to finanční, majetkovou a bonitu rozvojovou. Finanční bonita obcí je založena na hodnocení nejvýznamnějších parametrů hospodaření obcí. Posuzování vychází především z druhového a funkčního členění rozpočtové skladby a z obsahového hlediska je členěno do tří okruhů: prŕíjmy, výdaje a kvalita rozpočtového procesu. $Z$ hlediska hodnocení FS je možné využít ukazatel dluhové služby a zadluženost na obyvatele. Dle Lajtkepové (2017) existuje závislost zadluženosti (na osobu) na velikosti municipality, Linhartová a Němeček (2015) dokazují, že municipální zadlužení není tak vysoké ve srovnání s dluhem ČR a jen málo obcí toto zadlužení vykazuje.

Opluštilová (2012) představila souhrnné hodnocení finančního zdraví obcí, a to v rozsahu sedmi stupňů (A až D). Pro komplexní hodnocení bylo zvoleno pět ukazatelů z oblasti rozpočtového hospodaření s váhou $40 \%$, tři ukazatele likvidity (váha $20 \%$ ) a čtyři ukazatele zadluženosti (celková váha $40 \%$ ). Váhy byly stanoveny s ohledem na důležitost té které oblasti, přihlédnuto bylo $\mathrm{k}$ praxi využívané zejména některými úřady regionálních rad při posuzování obcí coby žadatelů o dotace. Tento způsob hodnocení finančního zdraví však v praxi není používán.

Délka i stav současného poznání na Slovensku je podobná situaci v ČR. Finanční stabilitu v souvislosti s finanční autonomií obcí prezentuje Poliak (2016), Tkáčová a Konečný (2017) vytvořili 13 indikátorů finanční stability a zkoumali ji v krajských městech na Slovensku. Z komplexnějších studií lze vyzdvihnout slovenskou metodiku Goliaše a kol. (2017), která je nazývána $\mathrm{INEKO}^{1}$ a je poskytována online. Hlavní výhodou je větší počet poměrových ukazatelů (15), čímž se efektivněji využívají vstupní data, která jsou prakticky totožná se SIMU. Problém srovnatelnosti obcí je zohledněn propočtem ukazatelů finančního zdraví obce na obyvatele. $\mathrm{V}$ oblasti likvidity se zaměřuje především na krátkodobou a střednědobou likviditu obce.

V zahraniční se problematika finanční stability či finančního zdraví analyzuje v dlouhodobějším horizontu a vychází ze situace 60. a 70. let minulého století, která znamenala pro mnoho municipalit začátek finanční problémů a nestability (Groves et al. 1981). Finanční stabilitu chápou výše uvedení autoři jako dlouhodobou schopnost (lokálních) vlád platit náklady na svou činnost, kdy byl pro její evaluaci v USA zaveden monitorovací systém finančních trendů (FTSM) zahrnující 12 indikátorů (finančních, environmentálních a organizačních). Podobně Cohen et al. (2012) definuje FS jako schopnost municipalit plnit své

\footnotetext{
${ }^{1}$ Název odvozen dle provozovatele serveru a společnosti tvůrce metodiky.
} 
finanční závazky a svými službami uspokojovat své občany. Sohl et al. (2009) použili pro zkoumání této problematiky municipalit v USA šesti-dimenzionální model, do kterého zahrnuli velikost populace, rozsah služeb, př́jmy a výdaje, územní velikost služeb, daňovou základnu a komunitní charakteristiky. Zafra-Gómez et al. (2009) pracovali s podobnými indikátory v př́padě španělských municipalit, podobně jako Lopez-Hernandez et al. (2012), kteří na vzorku více než 2300 obcí zkoumali dopady krize na FS obcí. Kazlauskiene a Aldukiene (2014) analyzovaly tuto problematiku v 38 litevských venkovských regionech.

Dle Honadlea et al. (2004) je s finanční stabilitou úzce spojena problematika finančního zdraví. Kanadský institut autorizovaných auditorů považuje tyto pojmy za ekvivalentní (CICA 1997) a určil 12 finančních indikátorů pro jejich měření (CICA 2009). Finanční zdraví bylo analyzováno také Hendrickovou (2004) v oblasti Chicaga, která vytvořila model otevřeného systému se třemi dimenzemi (prostředí, rovnováha fiskální struktury s prostředím a vlastnosti fiskální struktury), italské municipality z tohoto pohledu analyzovali Padovani et al. (2010). Finančním zdravím v 5 tisících obcích Španělska z hlediska dimenze udržitelnosti, flexibility zranitelnosti se zabývali Cabaleiro et al. (2012).

\section{Legislativní úprava hospodaření obcí a rozpočtové odpovědnosti}

Obce jsou veřejnoprávní korporace, které mohou vlastnit majetek a hospodařit dle rozpočtu (Zákon č. 128/2000 Sb., obcích). Usnesení vlády č. 346/2004, o Regulaci zadluženosti obcí a krajů pomocí ukazatele dluhové služby bylo prvním regulačním nařízením v oblasti řízení FS obcí. Následně bylo nahrazeno usnesením vlády č. 1395/2008 o monitoringu hospodaření obcí. Jak bylo již uvedeno, Ministerstvo financí provádí monitoring hospodaření obcí pomocí šestnácti informativních a dvou monitorujících ukazatelů, které tvoří soustavu informativních a monitorujících ukazatelů (SIMU). Jednotlivé ukazatele SIMU (struktura a popis výpočtu viz MFČR 2017) vycházejí z účetních podkladů dodaných obcí (FIN 2-12, rozvaha, výsledovka) a nejsou seskupovány či hodnoceny podle dílčích oblastí hodnocení hospodaření. Nevýhodu lze spatřovat v tom, že obec dostává zpětnou vazbu pouze ke dvěma ukazatelům, ke kterým jsou vypracovány doporučené hodnoty. Obec nemusí získat jasnou představu o pohotové likviditě nebo zohlednění krátkodobé versus dlouhodobé zadluženosti, stejně tak není zohledněna velikost obce.

V roce 2016 bylo do monitoringu zahrnuto všech 6254 samosprávných obcí České republiky (vč. hl. m. Prahy). K 31. prosinci 2016 byl ukazatel celkové likvidity v intervalu $\langle 0 ; 1\rangle$ u 110 obcí, podíl cizích zdrojů k celkovým aktivům byl vyšší než $25 \%$ u 122 obcí a oba ukazatele zároveň překročilo 11 obcí. Jde o meziroční pokles o 17 obcí, přičemž čtyři obce tyto hodnoty překročily již v některém roce $\mathrm{v}$ minulosti (MFČR 2017). Výsledné hodnoty ukazatelů pouze indikují možné riziko hospodářských problémů, ale nutně neznamenají, že je obec v tíživé finanční situaci. To lze vyhodnotit až na základě důkladnější analýzy finančních a účetních výkazů a zejména dodatečných podkladů poskytnutých samotnými obcemi. Je však diskutabilní, zda tento nástroj vede obce k větší obezřetnosti při hospodaření se svěřenými veřejnými prostředky, jelikož neexistuje provázanost mezi výsledky SIMU a finančními nároky obcí, není nijak omezen jejich nárok a př́stup k dotacím, výnosům ze sdílených daní apod.

Od února 2017 je omezena dluhová nezávislost obcí Zákonem č. 23/2017 Sb., o pravidlech rozpočtové odpovědnosti a Zákonem č. 24/2017 Sb., kterým se mění některé zákony v souvislosti s přijetím právní úpravy rozpočtové odpovědnosti. Zákon č. 23/2017 Sb. se vztahuje na veřejné instituce, kterými jsou mj. i územní samosprávné celky (ÚSC), a tedy i obce. Zákon o pravidlech rozpočtové odpovědnosti stanovuje pro ÚSC pravidlo dluhové 
brzdy (§ 14) a číselné fiskální pravidlo (§ 17). Dluhová brzda je stanovena tak, že pokud činí výše dluhu sektoru veřejných institucí nejméně 55 \% nominálního HDP, musí obec schválit svůj rozpočet na následující rok jako vyrovnaný či přebytkový. Rozpočet může být sestaven jako schodkový jen při splnění podmínek stanovených v § 4 odst. 6 zákona č. 250/2000 Sb. Fiskální pravidlo ukládá povinnost obci hospodařit tak, aby výše jeho dluhu nepřesáhla $60 \%$ průměru jeho př́ijmů za poslední čtyři rozpočtové roky. Pokud je tato hranice překročena, má obec povinnost postupně splácet předchozí dluhy alespoň o $5 \%$ z rozdílu mezi výší dluhu a $60 \%$ jeho průměrných př́ijmů za poslední čtyři rozpočtové roky. Definované fiskální pravidlo tedy nebrání obcím vzít si na financování svých projektů úvěr i v př́padě, kdy obec překračuje $60 \%$ limit, pokud je v letech následujících splácen alespoň o $5 \% \mathrm{z}$ rozdílu mezi dosaženou úrovní dluhu a $60 \%$ průměrného př́ijmu za poslední čtyři rozpočtové roky. Plnění pravidla se posuzuje vůči dluhu předchozího roku.

Podstatné je pro FS také vymezení dluhu. Dluhem ÚSC se dle $\S 17$ rozumí hodnota nesplacených závazků $\mathrm{z}$ vydaných dluhopisů, přijatých úvěrů, zápůjček a návratných finančních výpomocí, realizace plnění ze záruk a vystavených směnek. Dluh je vymezen jako dluh v nominální hodnotě, nesplacený ke konci roku. Konkrétně se do hodnoty dluhu započítávají stavy na syntetických účtech: 281, 282, 283, 289, 322, 326, 362, 451, 452, 453, 456 a 457, které vymezuje Vyhláška č. 410/2009 Sb.

\section{Návrh soustavy ukazatelů finanční stability}

Po důkladné analýze dostupných prístupů $\mathrm{k}$ hodnocení ( $\mathrm{v}$ kombinaci sekundárních a primárních zdrojů), sledování FS a zdraví obcí a diskuzi se zástupci 30 obcí a MSK v rámci pilotního testování, byly identifikovány dva kličcové předpoklady, které jsou důležité pro zajištění krátkodobé i dlouhodobé rozpočtové rovnováhy a udržitelnosti financování obcí. Konkrétně se jedná o to, že saldo běžného rozpočtu by vždy mělo být kladné (kapitálový rozpočet může být deficitní) a maximální dluhová služba (splátky dluhu plus placené úroky) by neměla převyšovat přebytek běžného rozpočtu.

Pro vyhodnocení finanční stability je navržena soustava ukazatelů, které jsou rozděleny vzhledem ke své povaze a obsahu do tří kategorií, a to indikátory hodnotící rozpočtové hospodaření, indikátory hodnotící zadluženost obce a indikátory hodnotící likviditu obce.

\subsection{Indikátory hodnotící rozpočtové hospodaření}

Rozpočtové hospodaření je důležitým aspektem činnosti obce spočívající zejména v kvalitním zabezpečení provozního hospodaření a v generování zdrojů pro rozvojové aktivity obce. Proto bylo vybráno sedm indikátorů rozpočtového hodnocení, jejichž způsob výpočtu je uveden $\mathrm{v}$ Př́loze 1.

1. Rozpočtové saldo $(R S)$ : ukazatel hodnotí rovnováhu municipálních financí. Hodnota ukazatele je vyjádřena $\mathrm{v}$ procentech. Může nabývat kladných i záporných hodnot. $\mathrm{V}$ př́padě že hodnota $R S$ je větší než nula jedná se o přebytek, v př́ípadě nulové hodnoty $R S$ hospodaří obec vyrovnaně a $\mathrm{v}$ př́padě záporné hodnoty $R S$ se jedná o deficit. Ten může být pokryt úvěrem či uspořenými prostředky minulých let. Rozpočtové hospodaření $\mathrm{v}$ daném roce lze považovat za:

- vyhovující pro $R S \geq 0$

- uspokojivé, pokud $R S<0$ a výše deficitu je nižší než zůstatky na bankovních účtech (krátkodobý finanční majetek) - je doporučena větší ostražitost v př́štích letech 
- neuspokojivé, když $R S<0$ a výše deficitu je vyšší než součet zůstatků na bankovních účtech a dlouhodobé termínované vklady municipality (krátkodobý finanční majetek + syntetický účet 068) - je nutné situaci řešit úvěrem a věnovat velkou pozornost přiměřenosti zadlužení obce.

2. Podíl přebytku běžného rozpočtu na běžných př́ijmech $(S B R)$ : ukazatel hodnotí základní předpoklad dlouhodobého úspěšného hospodaření obcí. Hodnota ukazatele je vyjádřena $\mathrm{v}$ procentech a může nabývat kladných i záporných hodnot. V př́padě že hodnota $S B R$ je větší než nula jedná se o přebytek na běžném účtu, v př́ípadě nulové hodnoty $S R S$ hospodaří obec na běžném účtu vyrovnaně a v př́padě záporné hodnoty $S B R$ se jedná o hospodaření deficitní. Rozpočtové hospodaření v daném roce lze považovat za:

- vyhovující pro $S R S \geq 0,25$.

- uspokojivé, pokud $0,25>S B R \geq 0$, doporučena je větší ostražitost v oblasti prŕpadného dalšího růstu běžných výdajů v budoucnu (např. v souvislosti se zajištěním budoucího provozu nových investičních akcí či úvěrování těchto investic)

- neuspokojivé, když $S B R<0$, je nutné situaci urychleně řešit hledáním úspor v oblasti běžných výdajů.

3. Podíl finančních zůstatků na účtech a pokladně k běžným výdajům $(B U K B V)$ : ukazatel vyjadřuje, jak dlouho je obec schopna financovat běžné výdaje úsporami $\mathrm{z}$ minulých let (krátkodobým finančním majetkem a dlouhodobými terminovanými vklady). Hodnota ukazatele je vyjádřena $\mathrm{v}$ měsících. Obec je schopna za předpokladu vyrovnaného hospodaření:

- př́i $B U K B V \geq 4$ měsíce - sanovat i dlouhodobější výpadek př́ijmů rozpočtu, aniž by musela činit restriktivní opatření v rámci běžných výdajů

- při výsledku 4 měsíce $>B U K B V \geq 1$ měsíc - sanovat pouze krátkodobý výpadek příjmů rozpočtu, aniž by musela činit restriktivní opatření v rámci běžných výdajů

- pro $B U K B V<1$ měsíc - není schopna za předpokladu vyrovnaného hospodaření sanovat jakýkoliv výpadek prŕíjmů rozpočtu, aniž by musela činit restriktivní opatření v rámci běžných výdajů.

4. Podíl finančních zůstatků na účtech a pokladně k běžným př́ijmům $(B U K B P)$ : ukazatel vyjadřuje, jakou část běžných ročních prŕjmů je obec schopna pokrýt svými úsporami (krátkodobým finančním majetkem a dlouhodobými termínovanými vklady). Hodnota ukazatele je vyjádřena $v$ procentech.

- Přri $B U K B P \geq 0,3$ je obec schopna sanovat i dlouhodobější výpadek př́jmů úsporami.

- Pokud 0,3 > BUKBV $\geq 0,08$, pak je schopna sanovat pouze krátkodobý výpadek př́imů rozpočtu úsporami.

- Když $B U K B V<0,08$, tak není schopna sanovat jakýkoliv výpadek př́ijmů úsporami.

5. Celkové konsolidované výdaje na běžných přrijmech $(K V B P)$ : ukazatel vypovídá o míře závislosti obce na kapitálových př́ijmech a investičních transferech. Ukazatel může nabývat kladných hodnot, přičemž čím více přesáhne daný ukazatel hodnotu jedna, tím větší je míra závislosti na poskytovaných investičních dotacích či kapitálových výnosech.

- Při $K V B P \leq 1$ obec není závislá na investičních transferech a kapitálových př́ijmech. 
- Pokud 1,2 > KVBP $\geq 1$, obec je mírně závislá na investičních transferech a kapitálových př́ijmech.

- Pro $K V B P>1,2$ je obec výrazně závislá na investičních transferech a kapitálových př́jmech. Pokud tato skutečnost není způsobena realizací významné investiční akce financované prostřednictvím investičních transferů, představuje to významné riziko pro dlouhodobou FS.

6. Přijaté transfery na kapitálových výdajích $(T R K V)$ : ukazatel vyjadřuje, jakou část kapitálových výdajů obec hradí prostřednictvím přijatých transferů. Hodnota ukazatele je vyjádřena $v$ procentech. Ukazatel může nabývat kladných hodnot, přičemž čím nižší je jeho hodnota, tím větší část kapitálových výdajů je schopna uhradit vlastními příjmy. Obec je v př́padě realizovaných investic:

- $\quad T R K V \leq 0,4$ mírně závislá na přijatých transferech

- $0,8>K V B P \geq 0,4$ středně závislá na přijatých transferech

- $\quad T R K V \geq 0,8$ vysoce závislá na přijatých transferech.

7. Podíl vlastních př́ijmů na celkových př́ijmech $(V P C P)$ : ukazatel vypovídá o finanční soběstačnosti obce a její nezávislosti na transferových př́ijmech. $V P C P$ vyjadřuje, jakou část př́ijmů pokrývá vlastními př́ijmy. Ukazatel může nabývat kladných hodnot a je vyjádřen $\mathrm{v}$ procentech. Čím větší je hodnota tohoto indikátoru, tím je obec více finančně soběstačná:

- $\quad V P C P \geq 0,9-$ obec s vysokou nezávislostí na transferových příjmech

- $09>V P C P \geq 0,8-$ obec je mírně závislá na transferových př́ijmech

- $\quad V P C P<0,8-$ obec je výrazně závislá na transferových př́ijmech.

Za předpokladu, že obec nerealizuje přebytkové hospodaření či z transferů nerealizuje investiční akci, lze poslední hodnotu považovat z hlediska dlouhodobé FS za rizikovou záležitost.

\subsection{Indikátory hodnotící zadluženost obce}

Zadluženost obce významným způsobem ovlivňuje nejen FS, ale i běžný chod obce. Patří tedy mezi klíčové oblasti, a proto je sledováno celkem 8 indikátorů (výpočet uveden v Př́loze 2). Některé z ukazatelů vycházejí ze SIMU, avšak oproti SIMU byl napřr. modifikován podíl cizích zdrojů a celkových aktiv, aby nedocházelo ke zkreslení z důvodu dotačních záloh. Výhodou pro obce je prezentované objasnění hodnot a možných rizik pro FS.

1. Podíl celkového dluhu na saldu běžného rozpočtu $(C D S B R)$ : ukazatel vyjadřuje, za kolik měsíců je obec schopna při dané úrovni salda běžného rozpočtu své dluhy splatit z tohoto salda. Ukazatel vypovídá o vlastní aktivitě a přístupu obce k plánování svých závazků a jejich možnému splácení. I když obec nemůže ovlivnit podstatnou část běžných př́ijmů $i$ běžných výdajů, musí brát jejich výši v úvahu při rozhodování o dalším zatížení rozpočtu $\mathrm{v}$ př́ípadě zadlužení. Je také nutné zohlednit, zda a $\mathrm{v}$ jakém časovém horizontu je schopna splatit své dluhy. Obec je schopna splatit své závazky:

- $\quad$ pro $C D S B R \leq 36 \mathrm{v}$ poměrně krátké době. Zadlužení nepředstavuje pro dlouhodobou FS jakékoliv ohrožení za předpokladu, že se obec nebude dále zadlužovat.

- při hodnotách $72 \geq C D S B R>36$ ve střednědobém horizontu. Zadlužení nepředstavuje pro dlouhodobou FS zásadnější riziko, avšak nedoporučuje se další zadlužování a je nezbytné věnovat pozornost vývoji běžných výdajů. 
- při $C D S B R>72$ pouze v dlouhém období. Z hlediska dlouhodobé FS výše tohoto zadlužení představuje poměrně vysoké riziko. Za předpokladu neexistence úspor $\mathrm{z}$ minulých let by obec neměla využívat další krátkodobé ani dlouhodobé úvěrové finanční prostředky a pečlivě zvažovat výši plánovaných výdajů v dalších letech.

2. Podíl dluhové služby a dluhové kapacity $(D S S B R)$ : ukazatel vyjadřuje, jak je obec schopna hradit své závazky ze salda běžného rozpočtu. Ukazatel vypovídá o tom, zda a jak dokáže zajistit prostředky na úhradu pravidelných splátek úvěrů různého typu. Hodnota ukazatele je vyjádřena $\mathrm{v}$ procentech. Obec je schopna zajistit platbu pravidelných splátek závazků z běžných př́ijmů:

- $\operatorname{pro} D S S B R \leq 0,4$ a je schopna část těchto př́jmů využít i pro investiční aktivity. Zadlužení a dluhová služba nepředstavují pro dlouhodobou FS jakékoliv ohrožení.

- pokud $0,8 \geq D S S B R>0,4$ a je schopna část těchto př́immů využít i pro investiční aktivity. Vzhledem k výši splátek však může zadlužení a dluhová služba představovat pro dlouhodobou FS určité riziko za předpokladu neočekáváného poklesu běžných př́ijmů či nárůstu běžných výdajů.

- v prrípadě $D S S B R>0,8$ jen za cenu své minimální investiční aktivity. Z hlediska dlouhodobé FS výše zadlužení představuje poměrně vysoké riziko. Za předpokladu neexistence úspor z minulých let mohou nastat problémy se splácením závazkủ.

3. Podíl placených úroků a dluhové kapacity $(P U S B R)$ : ukazatel vyjadřuje, jak je obec schopna hradit úrokové náklady $\mathrm{z}$ provozního salda. Jedná se o doplňkový ukazatel $\mathrm{k}$ ukazateli $D S S B R$. Hodnota ukazatele je vyjádřena v procentech. Obec je schopna zajistit platbu pravidelných splátek i úroků svých závazků z běžných př́jimů:

- když $P U S B R \leq 0,04$ a je schopna část těchto př́ijmů využít i pro investiční aktivity. Zadlužení a dluhová služba nepředstavuje pro dlouhodobou FS jakékoliv ohrožení.

- pokud $0,08 \geq P U S B R>0,04$ a je schopna část těchto př́ijmů využít i pro investiční aktivity. Vzhledem k výši splátek však může zadlužení a dluhová služba představovat pro dlouhodobou FS určité riziko za předpokladu neočekáváného poklesu běžných př́ijmů či nárůstu běžných výdajů.

- pro $P U S B R>0,08$ jen za cenu své minimální investiční aktivity. Z hlediska dlouhodobé FS výše zadlužení představuje poměrně vysoké riziko. Za předpokladu neexistence úspor z minulých let mohou vyvstat problémy se splácením závazků.

4. Podíl cizích zdrojů a celkových aktiv $(C Z C A)$ : ukazatel vyjadřuje míru krytí závazků celkovým majetkem (celkovými aktivy). Jedná se o jeden ze dvou stěžejních ukazatelů zahrnutých v SIMU (hodnota by neměla dle monitoringu přesáhnout $25 \%$ ). Zjištěná hodnota CZCA:

- $0,1 \geq C Z C A \geq 0$ značí nízký podíl cizích zdrojů na celkových aktivech. Riziko z pohledu dlouhodobé i krátkodobé FS je minimální.

- $\quad 0,25 \geq C Z C A \geq 0,1$ znamená významný podíl cizích zdrojů na celkových aktivech. Obec by měla obezřetně přistupovat především ke zvyšování svého dalšího zadlužení.

- CZCA >0,25 vyjadřuje vysoký podíl cizích zdrojů na celkových aktivech, který může představovat vysoké riziko z hlediska krátkodobé i dlouhodobé FS. Za předpokladu neexistence úspor $\mathrm{z}$ minulých let by obec neměla využívat další krátkodobé ani dlouhodobé úvěrové finanční prostředky.

5. Podíl cizích zdrojů bez dotačních záloh a celkových aktiv (CZCAl): ukazatel vyjadřuje míru krytí závazků, které v sobě nezahrnují dotační zálohy, celkovým majetkem (celkovými aktivy). Modifikace předcházejícího ukazatele, kdy cizí zdroje jsou očištěny o dotační zálohy, 
které mohou v rámci cizích zdrojů sehrávat významnou roli (pokud se jedná o dotace na velké investiční akce). Hodnota ukazatele je vyjádřena v procentech a značí:

- pro $0,1 \geq C Z C A 1 \geq 0$ nízký podíl cizích zdrojů na celkových aktivech. Riziko $\mathrm{z}$ pohledu dlouhodobé i krátkodobé finanční stability je minimální.

- při $0,25 \geq C Z C A 1 \geq 0,1$ významný podíl cizích zdrojů na celkových aktivech. Obec by měla obezřetně přistupovat především ke zvyšování svého dalšího zadlužení.

- pro $C Z C A 1>0,25$ vysoký podíl cizích zdrojů na celkových aktivech, který může představovat vysoké riziko $\mathrm{z}$ hlediska krátkodobé i dlouhodobé finanční stability. Za předpokladu neexistence úspor $\mathrm{z}$ minulých let by obec neměla využívat další krátkodobé ani dlouhodobé úvěrové finanční prostředky.

6. Podíl celkového dluhu na cizích zdrojích $(D C Z)$ : ukazatel vyjadřuje, jakým procentem se na cizích zdrojích podílí celkové zadlužení obce. Je doplňkovým indikátorem $\mathrm{k}$ výše uvedeným dvěma ukazatelům. Je součástí ukazatelů zahrnutých v SIMU. Hodnota ukazatele je vyjádřena $v$ procentech. Platí, že čím je procento nižší, tím je finanční situace municipality lepší.

7. Dluhová služba celkem $(D S C)$ : ukazatel vyjadřuje míru krytí celkového dluhu obce konsolidovanými př́ijmy v daném roce. Je součástí ukazatelů zahrnutých v SIMU (hodnota by neměla dle monitoringu přesáhnout $30 \%$ ). Podíl celkového dluhu na celkových konsolidovaných př́jmech obce je:

- nízký pro $D S C \leq 0,2$. Riziko z pohledu dlouhodobé i krátkodobé FS je minimální.

- významný pro $0,3 \geq D S C>0,2$. Obec by měla obezřetně přistupovat především ke zvyšování svého dalšího zadlužení.

- vysoký pro $D S C>0,3$ a může představovat vysoké riziko z hlediska krátkodobé i dlouhodobé FS. Za předpokladu neexistence významnějších úspor z minulých let by obec neměla využívat další krátkodobé ani dlouhodobé úvěrové finanční prostředky.

8. Podíl celkového dluhu na běžných př́ijmech $(D B P)$ : ukazatel vyjadřuje míru krytí celkového dluhu obce běžnými př́ijmy $\mathrm{v}$ daném roce. Je doplňkovým indikátorem k ukazateli „Dluhová služba celkem“. Hodnota ukazatele je vyjádřena v procentech. Podíl celkového dluhu na běžných př́ijmech je:

- nízký pro $D B C \leq 0,25$. Obec je z pohledu dlouhodobé i krátkodobé FS stabilní.

- významný pro $0,4 \geq D B C>0,25$. Obec by měla obezřetně přistupovat především ke zvyšování svého dalšího zadlužení.

- vysoký pro $D B C>0,4$ a může představovat vysoké riziko z hlediska krátkodobé $\mathrm{i}$ dlouhodobé FS. Za předpokladu neexistence významnějších úspor z minulých let by obec neměla využívat další krátkodobé ani dlouhodobé úvěrové finanční prostředky.

\subsection{Indikátory hodnotící likviditu obce}

Schopnost dostát krátkodobým i dlouhodobým závazkům zásadním způsobem ovlivňuje FS a celkovou finanční situaci obce. Jako klíčové byly identifikovány následující tři ukazatele a stanoveny jejich hodnoty. V Př́lloze 3 je uveden princip výpočtu indikátorů likvidity.

1. Celková (běžná) likvidita $(C L)$ : ukazatel vyjadřuje schopnost municipality dostát svým krátkodobým závazkům ze svých likvidních zdrojů. Je součástí ukazatelů zahrnutých v SIMU (hodnota by neměla $v$ tomto monitoringu být nižší než 1 ). Hodnota je vyjádřena $v$ absolutních číslech. Celková likvidita obce je:

- velmi nízká při $C L \leq 1$. Nízká schopnost dostát svým krátkodobým závazkům může představovat vysoké riziko $\mathrm{z}$ hlediska krátkodobé i dlouhodobé FS. 
- Přiměřená pro $5 \geq C L>1$, neměl by být problém plnit krátkodobé závazky za předpokladu, že nedojde k výraznému nárůstu krátkodobých závazků.

- Vysoká při $C L>5$. Neexistuje riziko neschopnosti dostát svým krátkodobým závazkům. Z pohledu dlouhodobé i krátkodobé FS je riziko minimální.

2. Okamžitá likvidita $(O L)$ : ukazatel vyjadřuje schopnost obce hradit své krátkodobé závazky s využitím finančního majetku (především zůstatků na běžných účtech). Je ve svém pojetí přísnější než ukazatel „Celkové likvidity“. Hodnota je vyjádřena v absolutních číslech. Okamžitá likvidita obce je:

- velmi nízká pro $O L \leq 1$. Nízká schopnost dostát svým krátkodobým závazkům $\mathrm{s}$ využitím finančního majetku může představovat vysoké riziko z hlediska krátkodobé $\mathrm{i}$ dlouhodobé FS.

- přiměřená při $1,75 \geq O L>1$. Obec by neměla mít problém plnit krátkodobé závazky za předpokladu, že nedojde $\mathrm{k}$ jejich výraznému nárůstu.

- vysoká pro $O L>1,75$. Minimální riziko neschopnosti dostát krátkodobým závazkům. $\mathrm{Z}$ pohledu dlouhodobé i krátkodobé FS je riziko minimální.

3. Finanční zásoba $(F Z)$ : ukazatel vyjadřuje schopnost obce pokrýt veškeré závazky z krátkodobého finančního majetku (především zůstatků na běžných účtech) a dlouhodobých termínovaných vkladů. Hodnota je $\mathrm{v}$ absolutních číslech a vyjadřuje:

- pro $F Z \leq 0,05$ velmi nízkou finanční zásobu obce. Nízká schopnost dostát svým krátkodobým a dlouhodobým závazkům s využitím krátkodobého finančního majetku může představovat vysoké riziko z hlediska krátkodobé i dlouhodobé FS.

- pro hodnoty $0,5 \geq F Z>0,05$ lze finanční zásobu obce považovat za přiměřenou, neměl by být problém plnit krátkodobé a dlouhodobé závazky za předpokladu, že nedojde $\mathrm{k}$ jejich výraznému nárůstu.

- při $F Z>0,5$ je obec z hlediska schopnosti pokrýt celkové závazky vysoce likvidní. Z pohledu dlouhodobé i krátkodobé FS je riziko minimální.

\subsection{Využití metodiky a indikátorů obcemi}

Navržená soustava ukazatelů je použitelná pro široký záběr činností obce, jelikož hodnotí rozpočtové hospodaření, oblast zadluženosti a likvidity. Výhodou je, že výpočet indikátorů je založen na údajích z povinně zveřejňovaných dokumentů (rozpočet obce, Výkaz FIN 2-12 výkaz pro hodnocení plnění rozpočtu ÚSC, rozvaha, výsledovka) a obce nebudou zatěžovány další administrativou.

Výslednou podobou soustavy indikátorů bude webová aplikace volně dostupná na stránkách MSK (zpř́stupnění se předpokládá během roku 2019), kde budou vypočteny a graficky znázorněny hodnoty všech indikátorů (s možností filtrování) pro každou obec MSK v přehledném grafu s vyznačenými aktuálními a doporučenými hodnotami a vysvětlující legendou. Ta bude obsahovat hodnocení a doporučení ve vztahu k FS, návaznost na základní zákonné požadavky ohledně rozpočtové kázně a další aktivity obce. Pro zjednodušení je snahou prezentovat hodnocení ve formě „semaforu“ (rozlišení bezproblémové zelené škály, k obezřetnosti nabádající oranžové škály a rizikové výsledky budou červené). Zároveň nebude FS a zdraví obce shrnuto do jednoho ukazatele pomocí přidělení vah, jelikož by při kumulaci mohlo dojít $\mathrm{k}$,zprůměrování“ některých negativních výsledků a tím i signalizace potenciálních rizik pro obec. 
Tento soubor indikátorů již byl otestován na, v úvodu předchozí kapitoly zmiňovaném vzorku 30 obcí MSK. ${ }^{2}$ Po důkladné analýze výsledků proběhla diskuze se zástupci obcí a MSK o úpravě kritérií hodnocení a hodnotách mezí, resp. doporučovaných hodnot pro jednotlivé indikátory. Proběhl sběr dat pro výpočet indikátorů pro všechny obce MSK, kdy chybějící data budou doplněna primárním výzkumem (dotazníkovým šetřením). Následně bude naplněna aplikace a bude vytvořena platforma (webová aplikace) pro propočet FS a zdraví obce.

Prezentovaná soustava indikátorů je vhodná a výhodná pro posouzení FS a zdraví obce zejména z následujících důvodů:

- komplexnost - hodnocení se zaměřuje na širokou základnu ukazatelů, které hodnotí FS a zdraví obce z mnoha hledisek

- jednoznačnost - každý ukazatel je přesně vymezen na základě konkrétních výpočtů, jejichž základem jsou povinně vykazované položky rozpočtu a rozvahy

- snadná dostupnost - on-line webová aplikace bude zdarma dostupná zainteresovaným obcím, navíc bez zátěže další administrativou

- rychlost - jelikož aplikace bude volně dostupná, starosta či jiný odpovědný člověk bude mít ihned a kdykoliv $\mathrm{k}$ dispozici adekvátní podklady pro to, aby mohl činit konkrétní nápravná opatření

- jednoduchost - snadná modifikace výběru a váhy ukazatelů a nastavení hodnocení dle potřeb obce či priorit zadavatele

- informovanost - zlepšení informovanosti obcí o jejich FS a zdraví a případných rizicích, které s dalším nezodpovědným hospodařením souvisí.

\section{Závěr}

Finanční stabilita obcí je jedním z klíčových předpokladů pro dlouhodobě udržitelný rozvoj, vytváření podmínek pro sociálně ekonomický rozvoj a plnění jejich základních úkolů. Cílem článku bylo vytvořit soustavu ukazatelů pro hodnocení FS a zdraví pro potřeby obcí, která využívá veřejně dostupné informace. Jistým limitem je v současné době omezenost aplikace na obce MSK. Metodika a soustava ukazatelů je však plně aplikovatelná i na jiné obce ČR a při dodržení platných legislativních zásad v zahraničních ekonomikách také na obce mimo území republiky.

Po analýze teoretických východisek a používaných přístupů k možnému hodnocení FS a zdraví obcí, byly za klíčové identifikovány dva základní předpoklady krátkodobé i dlouhodobé rozpočtové rovnováhy a udržitelnosti financování obcí. Konkrétně saldo běžného rozpočtu by vždy mělo být kladné (kapitálový rozpočet může být deficitní) a maximální dluhová služba (splátky dluhu plus placené úroky) by neměla převyšovat přebytek běžného rozpočtu. Následně byla sestavena soustava 18 indikátorů, která se zaměřuje na tři oblasti: rozpočtové hospodaření ( 7 indikátorů), zadluženost ( 8 indikátorů) a likviditu (3 indikátory). Pro každý indikátor je $\mathrm{k}$ dispozici jednoznačně definované a interpretovatelné hodnocení z hlediska finanční stability, možných rizik a návaznosti na základní zákonné požadavky ohledně rozpočtové kázně.

\section{Poděkování}

Článek vznikl za podpory projektu 02027/2017/FIN „Vytvoření metodiky a nástrojů sledování finančního zdraví obcí” v rámci dotačního programu Moravskoslezského kraje.

\footnotetext{
${ }^{2}$ Výsledky tohoto testování zatím není možno publikovat, a to na základě požadavku se zadavatelem projektu.
} 


\section{Literatura}

[1] ADRIAN, T., D. COVITZ and N. LIANG, 2015. Financial Stability Monitoring. Annual Review of Financial Economics, 7(1), 357-395. ISSN 1941-1367.

[2] BINEK, J. a kol., 2007. Venkovský prostor a jeho oživení. Brno: Georgetown. ISBN 80251-19-5.

[3] CABALEIRO, R., E. BUCH and A. VAAMONDE, 2012. Developing a Method to Assessing the Municipalities Financial Health. American Review of Public Administration, 43(6), 729-751. ISSN 0275-074.

[4] CEMR, 2017. Local finances. [online]. Council of European Municipalities and Regions, European section of United Cities and Local Governments, 8.3.2017. Dostupné z: http://www.ccre.org/en/actualites/view/3462.

[5] CICA, 1997. Indicators of governmental financial conditions. Toronto: Canadian Institute of Chartered Accountants. ISBN 978-08-8800-480-2.

[6] CICA, 2009. Public sector statement of recommended practice (SORP) 4. Indicators of financial condition. Toronto: Canadian Institute of Chartered Accountants.

[7] COHEN, S., M. DOUMPOS, E. NEOFYTOU and C. ZOPOUNIDIS, 2012. Assessing financial distress where bancruptcy is not an option: An aleternative approach for local municipalities. European Journal of Operational Research, 218, 270-279. ISSN 03772217.

[8] GOLIAŠ, P., P. KLÁTIK a M. TUNEGA, 2017. Hospodarenie obcí. [online]. Dostupné z: http://www.hospodarenieobci.sk/oprojekte/.

[9] GROVES, S. M., W. M. GODSEY and M. A. SHULMAN, 1981. Financial Indicators for Local Government. Public Budgeting \& Finance, 1(2), 5-19. ISSN:1540-5850.

[10] HALÁSEK, D., J. BINEK a J. LEGÁTOVÁ, 2005. Analýza ekonomické připravenosti obci a jejich možnosti řešit své rozvojové potřeby. Závěrečná zpráva za aktivitu A6 výzkumného projektu MMR WB 29-04. Brno: GaREP, Vysoká škola logistiky.

[11]HALÁSEK, D., J. BINEK a J. LEGÁTOVÁ, 2006. Ekonomický potenciál obcí. Závěrečná zpráva za aktivitu A11 výzkumného projektu MMR WB 29-04. Brno: GaREP.

[12] HALÁSEK, D., J. PILNÝ a P. TOMÁNEK, 2002. Určování bonity obcí. Ostrava: VŠBTU Ostrava. ISBN 80-248-0159-0.

[13] HALÁSKOVÁ, M., 2013. Př́stupy k financování veřejných služeb v zemích EU. Scientific Papers of the University of Pardubice. Series D, Faculty of Economics and Administration, 20(27), 59-71. ISSN 1211-555X.

[14] HENDRICK, R. M., 2004. Assessing and Measuring the Fiscal Heath of Local Governments Focus on Chicago Suburban Municipalities. Urban Affairs Review, 40(1), 78-114. ISSN 1078-0874.

[15] HONADLE, B. W., J. M. COSTA and B. A. CIGLER, 2004. Fiscal health for local governments. San Diego, CA: Elsevier Academic Press. ISBN 978-01-2354-751-4.

[16] KADEŘÁBKOVÁ, J. a J. PEKOVÁ, 2012. Územní samospráva - udržitelný rozvoj a finance. Praha: Wolters Kluwer. ISBN 978-80-7357-910-4.

[17] KAZLAUSKIENE, V. and L. AIDUDIENE, 2014. Assessing the Financial Condition of Lithuanian Municipalities in Rural Regions. Economic Science for Rural Development, 33, 108-116. ISSN 1691-3078. 
[18] LAJTKEPOVÁ, E., 2017. Indebtness of Statutory Cities in the Czech Republic. Acta academica karviniensia, 17(4), 59-68. ISSN 1212-415X.

[19] LINHARTOVÁ, V. and L. NĚMEČEK, 2015. An Analysis of Municipal Indebtness. Acta academica karviniensia, 15(4), 54-66. ISSN 1212-415X.

[20] LOPEZ-HERNANDEZ, A. M., J. L. ZAFRA-GOMEZ and D. ORTIZ-RODRIGUEZ, 2012. Effects of the crisis in Spanish municipalities' financial condition: an empirical evidence (2005-2008). International Journal of Critical Accounting, 4(5-6), 631-645. ISSN: 1757-9848.

[21] MFČR, 2017. Ukazatele SIMU. [online]. Dostupné z: http://www.mfcr.cz/cs/verejnysektor/uzemni-rozpocty/monitoring-hospodareni-obci.

[22] OPLUŠTILOVÁ, I., 2012. Finanční zdraví obci a jeho regionální diferenciace. Disertační práce. Brno: Masarykova univerzita v Brně.

[23] OTRUSINOVÁ, M. a D. KUBÍČKOVÁ, 2011. Finanční hospodaření municipálních účetnich jednotek: po novele zákona o účetnictví. Praha: C. H. Beck. ISBN 978-80-7400342-4.

[24] PADOVANI, E., M. F. ROSSI and R. L. ORELLI, 2010. The Use of Financial Indicators to Determine Financial Health of Italian Municipalities. [online]. Dostupné z: https://ssrn.com/abstract=1679128.

[25] PEKOVÁ, J., 2008. Veřejné finance: úvod do problematiky. Praha: Wolters Kluwer. ISBN 978-80-7357-358-4.

[26] POLIAK, L., 2016. Finančná autonómia obcí - mikroekonomické východiská. Societas et Iurisprudentia, 4(1), 122-138. ISSN 1339-5467.

[27] SOHL, S., M. T. PEDDLE, K.THURMAIER, C. H. WOOD and G. KUHN, 2009. Measuring the Financial Position of Municipalities: Numbers Do Not Speak for Themselves. Public Budgeting \& Finance, 2009, 29(3), 74-96, ISSN:1540-5850.

[28] TKÁČOVÁ, A. a P. KONEČNÝ, 2017. Krajské mestá Slovenska a ich finančné zdravie. Scientific papers of the University of Pardubice. Series D, Faculty of Economics and Administration, 41, 193-205. ISSN 1211-555X.

[29] Usnesení vlády ČR ze dne 12. listopadu 2008 č. 1395 o monitoringu hospodaření obcí.

[30] Usnesení vlády č. 346/2004 o Regulaci zadluženosti obcí a krajů pomocí ukazatele dluhové služby.

[31] ZAFRA-GOMÉZ, J. L., A. M. LÓPEZ-HERNÁNDEZ and A. HERNÁNDEZBASTIDA, 2009. Developing a Model to Measure Financial Condition in Local Government: Evaluating Service Quality and Minimizing the Effects of the Socioeconomic Environment: An Application to Spanish Municipalities. The American Review of Public Administration, 39(4), 425-449. ISSN 0275-074.

[32] Zákon č. 128/2000 Sb., o obcích (obecní zřízení).

[33] Zákon č. 23/2017 Sb., o pravidlech rozpočtové odpovědnosti.

[34] Zákon č. 24/2017 Sb., kterým se mění některé zákony v souvislosti s přijetím právní úpravy rozpočtové odpovědnosti.

[35] Zákon č. 250/2000 Sb., o rozpočtových pravidlech územních rozpočtů. 
[36] ŽÁRSKÁ, E., 2009. Finančná kapacita obce ako determinant rozvoja. In Teoretické a praktické aspekty verejných financí [online]. Praha: VŠE. ISBN 978-80-245-1513-7. Dostupné z: http://kvf.vse.cz/storage/1239811888_sb_zarska.pdf. 
Příloha 1: Výpočet indikátorů rozpočtového hospodaření

\begin{tabular}{|c|c|c|}
\hline Zkratka & Indikátor & Způsob výpočtu \\
\hline $\mathrm{RS}$ & Rozpočtové saldo & $\begin{array}{l}\text { (Celkové konsolidované př́ijmy - Celkové konsolidované výdaje) / } \\
\text { Celkové konsolidované př́ijmy }\end{array}$ \\
\hline SBR & $\begin{array}{l}\text { Podíl přebytku běžného } \\
\text { rozpočtu na běžných } \\
\text { př́ijmech }\end{array}$ & $\begin{array}{l}\text { (Běžné př́ijmy - Konsolidované běžné výdaje) / Běžné příijmy nebo } \\
\text { (Daňové příjmy + Nedaňové př́ijmy + Přijaté neinvestiční transfery - } \\
\text { Konsolidované běžné výdaje) / (Daňové př́ijmy + Nedaňové př́ijmy + } \\
\text { Přijaté neinvestiční transfery) }\end{array}$ \\
\hline BUKBV & $\begin{array}{l}\text { Podíl finančních zůstatků } \\
\text { na účtech a pokladně k } \\
\text { běžným výdajům }\end{array}$ & $\begin{array}{l}\text { (Krátkodobý finanční majetek + Dlouhodobé termínované vklady) / } \\
\text { Konsolidované běžné výdaje *12 }\end{array}$ \\
\hline BUKBP & $\begin{array}{l}\text { Podíl finančních zůstatků } \\
\text { na účtech a pokladně } \mathrm{k} \\
\text { běžným příjmům }\end{array}$ & $\begin{array}{l}\text { (Krátkodobý finanční majetek + Dlouhodobé termínované vklady) / Běžné } \\
\text { př́ijmy }\end{array}$ \\
\hline KVBP & $\begin{array}{l}\text { Celkové konsolidované } \\
\text { výdaje na běžných prŕjimech }\end{array}$ & $\begin{array}{l}\text { Celkové konsolidované výdaje / Běžné příjmy } \\
\text { nebo Celkové konsolidované výdaje / (Daňové přijmy + Nedaňové př́ijmy } \\
+ \text { Přijaté neinvestiční transfery) }\end{array}$ \\
\hline TRKV & $\begin{array}{l}\text { Přijaté transfery na } \\
\text { kapitálových výdajích }\end{array}$ & Přijaté transfery / Kapitálové výdaje \\
\hline VPCP & $\begin{array}{l}\text { Podíl vlastních př́ijmů na } \\
\text { celkových př́ijmech }\end{array}$ & $\begin{array}{l}\text { Vlastní příjmy / Celkové konsolidované příjmy nebo } \\
\text { (Daňové př́ijmy + Nedaňové př́ijmy + Kapitálové prŕíjmy) / Celkové } \\
\text { konsolidované př́ijmy }\end{array}$ \\
\hline
\end{tabular}

Zdroj: autorské výpočty.

Př́loha 2: Výpočet indikátorů zadluženosti

\begin{tabular}{|c|c|c|}
\hline Zkratka & Indikátor & Způsob výpočtu \\
\hline CDSBR & $\begin{array}{l}\text { Podíl celkového dluhu na } \\
\text { saldu běžného rozpočtu }\end{array}$ & $\begin{array}{l}\text { (Celkový dluh / (Běžné př́ijmy - Konsolidované běžné výdaje + Placené } \\
\text { úroky)*12 }\end{array}$ \\
\hline DSSBR & $\begin{array}{l}\text { Podíl dluhové služby a } \\
\text { dluhové kapacity }\end{array}$ & $\begin{array}{l}\text { (Placené úroky + Splátky emitovaných dluhopisů + kladný výsledek } \\
\text { rozdílu splátek krátkodobých přijatých půjčených prostředků a } \\
\text { krátkodobých přijatých půjčených prostředků + kladný výsledek rozdílu } \\
\text { splátek dlouhodobých přijatých půjčených prostředků a dlouhodobých } \\
\text { přijatých půjčených prostředků) / (Běžné př́ijmy - konsolidované běžné } \\
\text { výdaje + Placené úroky) }\end{array}$ \\
\hline PUSBR & $\begin{array}{l}\text { Podíl placených úroků a } \\
\text { dluhové kapacity }\end{array}$ & $\begin{array}{l}\text { Placené úroky / (Běžné př́ijmy - Konsolidované běžné výdaje + Placené } \\
\text { úroky) }\end{array}$ \\
\hline CZCA & $\begin{array}{l}\text { Podíl cizích zdrojů a } \\
\text { celkových aktiv }\end{array}$ & $\begin{array}{l}\text { Cizí zdroje / Celková aktiva } \\
\text { nebo Cizí zdroje / (Stálá aktiva + Oběžná aktiva) }\end{array}$ \\
\hline CZCA1 & $\begin{array}{l}\text { Podíl cizích zdrojů bez } \\
\text { dotačních záloh a } \\
\text { celkových aktiv }\end{array}$ & $\begin{array}{l}\text { (Cizí zdroje - Dlouhodobé přijaté zálohy na transfery) / Celková aktiva } \\
\text { Nebo (Cizí zdroje - Dlouhodobé přijaté zálohy na transfery) / (Stálá aktiva } \\
\text { + Oběžná aktiva) }\end{array}$ \\
\hline $\mathrm{DCZ}$ & $\begin{array}{l}\text { Podíl celkového dluhu na } \\
\text { cizích zdrojích }\end{array}$ & Celkový dluh / Cizí zdroje \\
\hline DSC & Dluhová služba celkem & Celkový dluh / Celkové konsolidované příjmy \\
\hline DBP & $\begin{array}{l}\text { Podíl celkového dluhu na } \\
\text { běžných př́ijmech }\end{array}$ & $\begin{array}{l}\text { Celkový dluh / Běžné př́ijmy nebo } \\
\text { Celkový dluh / (Daňové př́ijmy + Nedaňové př́ijmy + Přijaté neinvestiční } \\
\text { transfery) }\end{array}$ \\
\hline
\end{tabular}

Zdroj: autorské výpočty.

Př́loha 3: Výpočet indikátorů likvidity

\begin{tabular}{|c|l|l|}
\hline Zkratka & Indikátor & Způsob výpočtu \\
\hline CL & Celková (běžná) likvidita & Oběžná aktiva / Krátkodobé závazky \\
\hline OL & Okamžitá likvidita & Krátkodobý finanční majetek / Krátkodobé závazky \\
\hline FZ & Finanční zásoba & $\begin{array}{l}\text { (Krátkodobý finanční majetek + Dlouhodobé termínované vklady) / } \\
\text { (Krátkodobé závazky + Dlouhodobé závazky) }\end{array}$ \\
\hline
\end{tabular}

Zdroj: autorské výpočty. 